\title{
Residential Mobility and Dental Decoration in Early Medieval Spain: Results from the Eighth Century Site of Plaza del Castillo, Pamplona
}

\author{
Eleanna Prevedorou ${ }^{1}$, Marta Díaz-Zorita Bonilla ${ }^{2}$, Alejandro Romero ${ }^{3}$, Jane E. Buikstra ${ }^{1}$, M. Paz de \\ Miguel Ibáñez ${ }^{4}$, Kelly J. Knudson ${ }^{1}$ \\ ${ }^{1}$ Center for Bioarchaeological Research, School of Human Evolution and Social Change, Arizona State University, \\ Tempe, AZ 85287-2402 \\ ${ }^{2}$ Department of Archaeology, Durham University, United Kingdom \\ ${ }^{3}$ Department of Biotechnology, University of Alicante, Spain \\ ${ }^{4}$ Department of Prehistory, University of Alicante, Spain
}

ABSTRACT Excavations at Plaza del Castillo in Pamplona (northern Spain) revealed a large Islamic necropolis dating to the eighth century A.D., including the skeleton of an adult female showing intentional dental modification (PLA-159). While the practice of dental decoration was virtually absent in Medieval Spain, it is common in Africa and suggests that this individual was born in Africa and brought to Spain later in life. The historically documented occupation of Pamplona by Muslim groups from northern Africa between ca. 715 and 799 A.D. also supports an African origin. As an additional line of evidence, we investigated the geographic origins of two individuals from the cemetery, including PLA-159, via radiogenic strontium and stable oxygen isotope analyses on enamel hydroxyapatite.

The Muslim conquest of the Iberian Peninsula in the Early Middle Ages constitutes an important part in the history of Spain, known from historical sources yet archaeologically unexplored. Excavations at Plaza del Castillo in the city of Pamplona in northern Spain (Fig. 1) recovered a large Islamic cemetery dating to the eighth century A.D. The identification of intentional dental modification in the cemetery, a practice virtually absent in Medieval Spain but common in African groups, may suggest an African origin for part of the burial sample, a hypothesis also supported by the historically documented arrival of Berbers from North Africa during the time of Muslim occupation. Hence, the reconstruction of the geographic origins of the individuals interred at Plaza del Castillo will afford unique insight about the Islamic occupation of the city of Pamplona, as well as about the diffusion of Muslim groups in Iberian Peninsula during the eighth century A.D.

Here we report the results of the preliminary study on migration in Early Medieval Pamplona using biogeochemical analysis. In the last decade, the use of biogeochemistry to address past residential mobility and migration has provided an invaluable new line
The human isotopic signatures were measured following established methodologies and compared to the local geochemical composition and modern precipitation values. The data analysis showed a non-local isotopic signature for both individuals, suggesting that they moved to Pamplona following childhood, probably from northern Africa, during the Islamization of the city. Stable carbon isotope analysis revealed a diet heavily based on $\mathrm{C}_{3}$ terrestrial plants. Overall, this preliminary data set exemplifies the use of biogeochemistry as an analytical tool, and provides unique insight about the diffusion of Muslim groups into the Early Medieval Iberian Peninsula. Dental Anthropology 2010;23(2):42-52.

of evidence and a growing field in archaeological science. The methodology, introduced to archaeology from environmental and ecological studies, has been successfully applied to numerous studies in a variety of historic and prehistoric contexts with a wide geographic range. Mobility and migration via isotopic analysis have been examined, for example, in the American Southwest (e.g., Ezzo et al., 1997; Ezzo and Price, 2002; Price et al., 1994), Mesoamerica (e.g., Price et al., 2006; White et al., 2004), south central Andes (e.g., Knudson and Buikstra, 2007; Knudson and Price, 2007; Knudson and Torres-Rouff, 2009), South Africa (Cox and Sealy, 1997), and Thailand (e.g., Bentley et al., 2007). In Europe, isotopic studies of geographic origins have been conducted in England (e.g., Montgomery et al., 2005), Central Europe (e.g., Bentley et al., 2004; Bentley and Knipper, 2005; Price et al., 1998; 2001),

Correspondence to: Eleanna Prevedorou, Center for Bioarchaeological Research, School of Human Evolution and Social Change, Arizona State University, PO Box 87402, Tempe AZ 85287-2402

email: eprevedo@asu.edu 


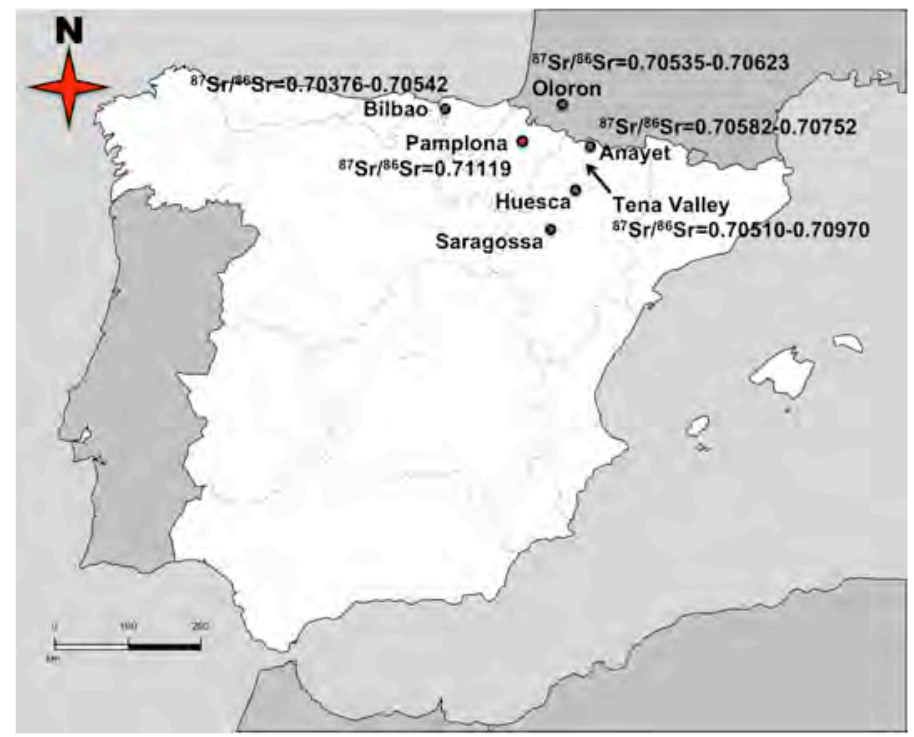

Fig. 1. Map of Iberian Peninsula showing the location of Pamplona with observed radiogenic strontium isotope signatures in bedrock and soil.

Iceland (e.g., Price and Gestsdóttir, 2006), the Alps (e.g., Müller et al., 2003), Spain (Díaz-Zorita Bonilla et al., 2009; Prevedorou et al., 2009), and Greece (e.g., Nafplioti, 2008; Richards et al., 2008).

In this paper, we use biogeochemistry to test hypotheses explicitly formed by the bioarchaeological and historical evidence. We begin by presenting the site of Plaza del Castillo, along with the history of the region. We provide an analytical description of the typology, technique, and origin of the case of dental decoration observed in the Islamic cemetery, and we present our research objectives. We continue by introducing biogeochemistry as an analytical tool to address human behavior, and we then describe the materials and laboratory methodology for this study. Finally, we present our results and discuss the interpretation of this preliminary data set, as well as future research.

\section{ARCHAEOLOGICAL AND HISTORICAL BACKGROUND: THE SITE OF PLAZA DEL CASTILLO}

The cemetery of Plaza del Castillo, located in the city of Pamplona, came to light in 2002 during the construction of an underground parking lot (Fig. 2a). The large Islamic necropolis, maqbara in Arabic, was located outside the city walls covering an area of $4000 \mathrm{~m}^{2}$; however, the total area of the cemetery is not yet known. Of the 160 undisturbed burials recovered in total, $50 \%$ were juveniles, while the adult burials consisted of approximately equal numbers of male and female individuals. Following the Islamic funerary traditions, the burials were single inhumations that lacked grave goods; bodies were placed in a simple pit lying on their right sides, with head towards southsoutheast facing the holy city of Mecca (Casal, 2003; Faro Carballa et al., 2007; de Miguel Ibáñez, 2007) (Fig. 2a,b). The date of the Islamic cemetery corresponds with the emergence of the Islamic control in the Iberian Peninsula in eighth century A.D. and constitutes the first definite archaeological evidence for the Muslim occupation of the city of Pamplona.

According to historic sources, Pamplona came under Islamic authority around 715 A.D. with the arrival of Muslim groups, mostly Berbers, from North Africa (Maghreb). The city remained under Muslim control until 799 when the ruler Mutarrif ibn Musa was assassinated (Faro Carballa et al., 2007-2008). Radiocarbon dating conducted thus far in one of the skeletons from Plaza del Castillo (Burial 32) yielded a date between 660 and 770 cal. A.D. (Beta-218654). Hence, the onset of the Muslim authority in Pamplona in 715, and the radiocarbon date of Burial 32 suggest that at least part of the Plaza del Castillo cemetery was in use during the initial Islamization and the ensuing expansion of the Muslim community in the city.

The discovery of the maqbara is of great significance for the reconstruction of the historical trajectory of Pamplona and northern Spain in general. Despite the belief that the conquest of the city took place with a pact between the conquerors and those conquered, it appears that the Islamic occupation went through several crises that necessitated military intervention. Arabic sources report that during Uqba's rule (probably in 734 A.D.), he had to suppress his opponents and take over their cities and that he was the one who conquered the city of Arbona, subjugated Galicia and Pamplona, and brought in Muslim people (Al-Marrakusi, 1999). Thus, the individuals buried at Plaza del Castillo could in fact represent the Muslims first arriving in Pamplona, coming to suppress the continuous revolutions of the time in the name of Emir.

\section{DENTAL DECORATION IN PLAZA DEL CASTILLO}

Skeletal analysis of the human remains from the Islamic necropolis has identified the presence of intentional dental modification in the anterior dentition of Burial 159 (PLA159), an adult female (Fig. 2b) (Romero et al., 2009). The modified teeth were classified following the typology established by Romero Molina (1986), which constitutes the most complete classification system based on earlier revisions (Saville, 1913; Romero Molina, 1958; Rubín De la Borbolla, 1940). Scanning electron microscopy (SEM) was performed on casts and replicas of the teeth to examine in detail the modified surfaces. Silicon Coltène ${ }^{\circledR}$ President Plus Jet and epoxy transparent resin Araldite 2020 were used for the dental casts and replicas respectively, following established methodologies (Galbany et al., 2006; Romero and De Juan, 2003). The dental replicas were analyzed with a SEM Hitachi S3000N at a magnification of 30X (Servicios Técnicos Investigación, Universidad de Alicante). 

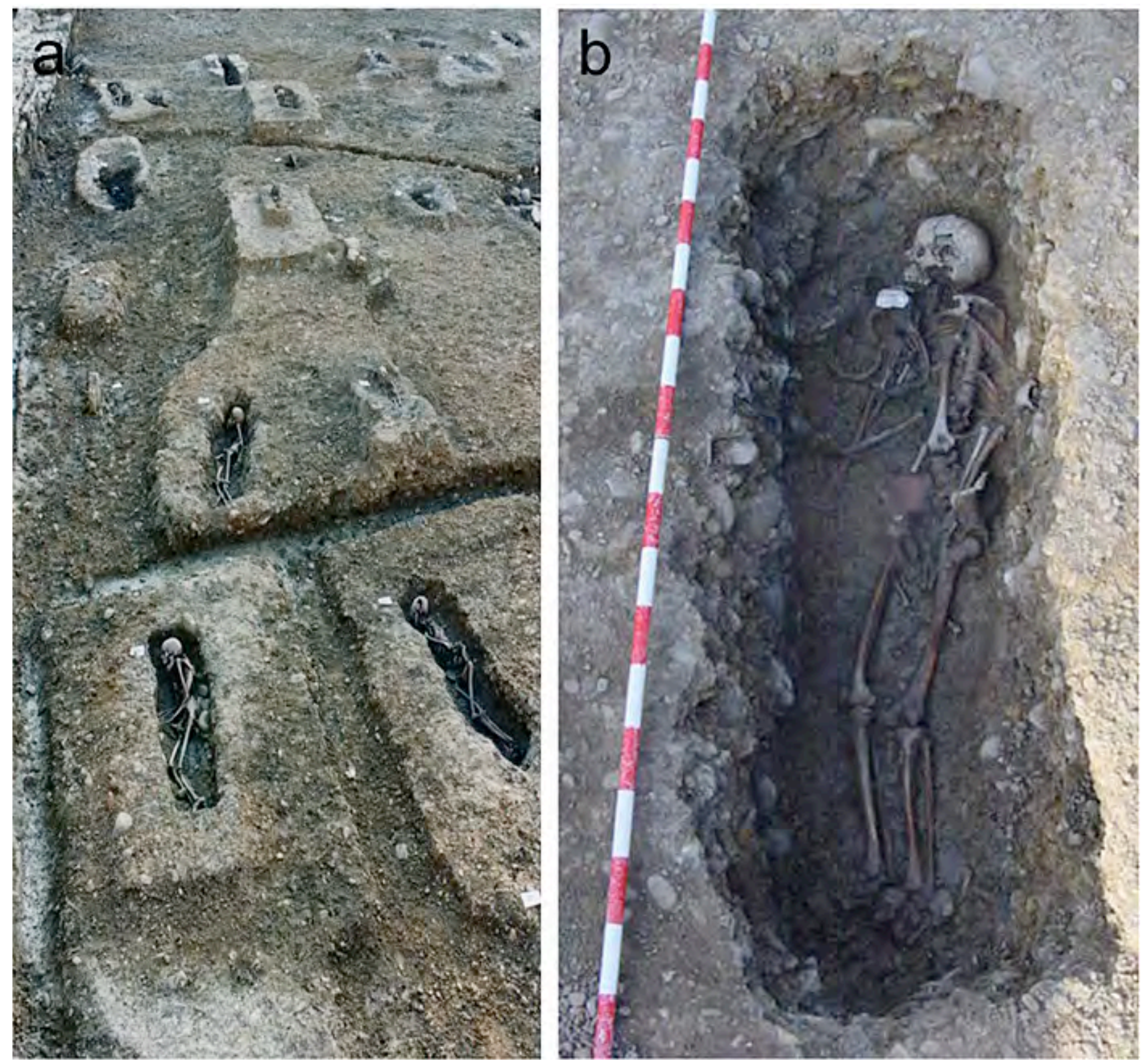

Fig. 2. View of the Islamic cemetery of Plaza del Castillo in Pamplona during excavation, showing the uniformly oriented burials $(\boldsymbol{a})$ and individual PLA-159 in situ $(\boldsymbol{b})$ (photo courtesy of Gabinete Trama de Arqueología, Pamplona) [Color figure can be viewed in the electronic (PDF) version of the journal.].

Individual PLA-159 showed dental modifications in 5 out of the 27 preserved teeth. Missing teeth included agenesis of the mandibular right third molar; the maxillary left first and second incisors and canine were lost postmortem. Modifications were identified on the mesial and distal surfaces of the maxillary right first incisor; the mesial and distal surfaces of the maxillary right second incisor; the mesial surface of the maxillary right canine; the mesial surface of the manbibular left first incisor; and the mesial surface of the mandibular right second incisor (Fig. 3a,b). The mandibular right first incisor was not intentionally modified and thus it was used for biochemical analysis.
The pattern of dental modification in individual PLA159 matches the general types of B and C (following Romero Molina, 1986). According to anthropological and ethnographical literature on Mesoamerica and Africa, dental modification was preferentially performed on the six maxillary anterior teeth (Goose, 1963; Romero Molina, 1958). However, modification of the mandibular dentition is also reported (e.g., this study; Fastlicht, 1976; Lagunas and Karam, 2003; Romero Molina, 1958). Intentional modification primarily of the maxillary incisors and canines, with extraction of the mandibular anterior teeth has been documented in various modern and ancient 

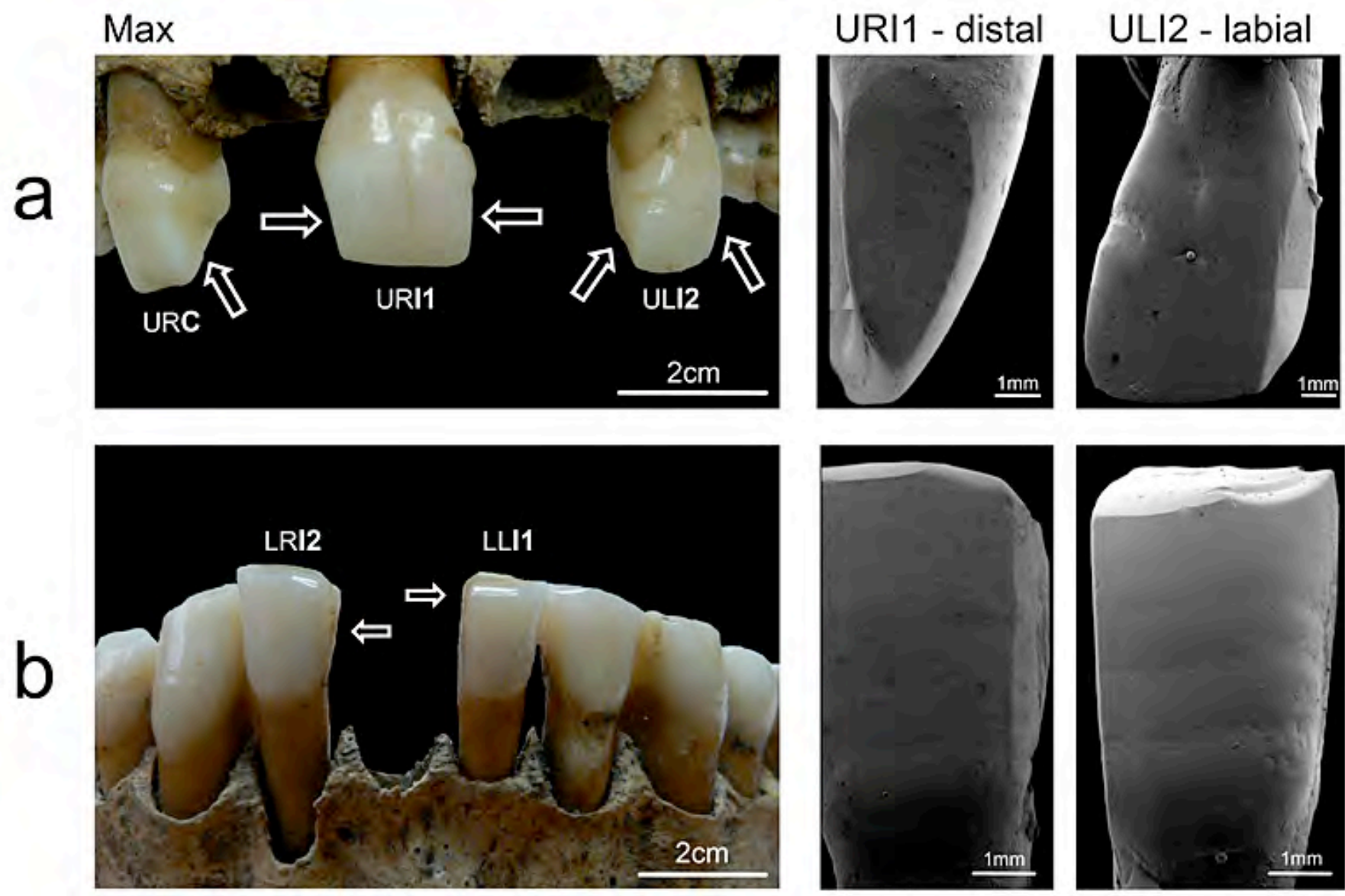

Mand
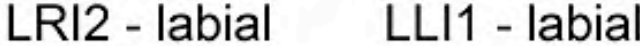

Fig. 3. Macroscopic and microscopic (SEM) views of the dental modifications present in individual PLA-159 in maxillary (a) and mandibular dentition (b) (photo by A. Romero). Abbreviations are: upper right first incisor (URI1); upper left second incisor (ULI2); upper right canine (UCR); lower right second incisor (LRI2); lower left first incisor (LLI1). [Color figure can be viewed in the electronic (PDF) version of the journal.]

African groups (Lagunas and Karam, 2003; Muwazi et al., 2005; Pindborg, 1969; Van Rippen, 1918). Typological analyses places the dental modifications of PLA-159 among the ones reported for African groups (Haour and Pearson, 2005; Tiesler, 2002). Primarily in western, central, and southern Africa, intentional dental modification of the anterior teeth in some cases consists of filing one or both interproximal sides, thereby destroying the incisal axis (Finucane et al., 2008; Gould et al., 1984; Jones, 1992; Reichart et al., 2007). This is similar to the modifications observed in African individuals resettled in the Americas during the period of colonization (Tiesler, 2002; Price et al., 2006) and in Iberian Peninsula during 13th to 15th centuries A.D. (Gonzalo et al., 2001). Among the types closest to the modifications observed in Plaza del Castillo are the ones reported for western Africa regions such as the Niger (Haour and Pearson, 2005:431), wherein the shape of the tooth was modified without affecting the occlusal surface. However, no parallel types have yet been found for the removal of the enamel up to the cervical area as observed in individual PLA-159 (Fig. 3b).

Documentation of the practice of dental decoration in the Iberian Peninsula is scarce. Dental modifications have been observed as part of post-mortem ritual in prehistoric Spain (Campillo et al., 2001). One case of an adult male of a possible sub-Saharan origin with intentional dental modification is documented from a more recent Islamic cemetery (13th to 15th centuries A.D.) in Spain (Gonzalo et al., 2001). A number of examples of dental modification are reported in Portugal in later periods, associated with the trade of slaves, mostly unpublished. Thus, the occurrence, as well as the typology of intentional dental modification at Plaza del Castillo suggest an African origin for PLA-159 and argue for the presence of first-generation immigrants in the cemetery.

\section{RESEARCH OBJECTIVES}

The presence of the Islamic cemetery in Pamplona coincides with the conquest of the city by Muslim groups in eighth century A.D. In particular, the identification of 
the adult female PLA-159 showing dental decoration in Plaza del Castillo raises significant questions regarding the geographic origins of the individuals buried in the maqbara. While the practice of dental modification was generally absent in Early Medieval Spain, it is commonly documented in African groups suggesting that PLA-159 was not part of the indigenous population. The historically documented episodic arrival of Muslim groups, mostly Berbers, from North Africa (Maghreb) in the Iberian Peninsula during the eighth century A.D. also supports an African origin for the individuals buried in Plaza del Castillo. Nevertheless, during the Muslim occupation part of the local population did convert to Islam, and interaction between the two religious groups is suggested by the recovery of rings with Arabic inscriptions in Kufic script in two contemporaneous Christian cemeteries in Pamplona (Faro Carballa et al., 2007-2008).

Hence, the question raised by the bioarchaeological evidence is whether the individuals buried in the maqbara were born in Pamplona or alternatively in Africa, brought in Spain later in life as part of the first generation of the incoming Muslim groups during the Islamization of the city. Specifically, determining the youthful residence of PLA-159 reveals important information regarding the nature of dental modification and its presence in Medieval Spain. To test the hypothesis of a non-local geographic origin and to begin exploring the residential histories of the individuals buried in Plaza del Castillo radiogenic strontium and stable oxygen isotope analyses were performed in a preliminary data set: the female PLA159 showing dental decoration, and the adult PLA-28 of indeterminate sex without evidence of dental decoration. In addition, stable carbon isotope analysis was conducted to reconstruct paleodiet.

\section{HUMAN BEHAVIOR THROUGH BIOGEOCHEMISTRY: GENERAL PRINCIPLES}

\section{Radiogenic strontium isotope analysis}

Strontium is an alkaline earth element, and occurs naturally in four isotopes, the radiogenic ${ }^{87} \mathrm{Sr}(7.04 \%)$ and the stable isotopes ${ }^{84} \mathrm{Sr}(\sim 0.56 \%),{ }^{86} \mathrm{Sr}(\sim 9.87 \%)$ and ${ }^{88} \mathrm{Sr}(\sim 82.53 \%)$ (Bentley, 2006$)$. Given that the radiogenic ${ }^{87} \mathrm{Sr}$ is formed over time by the radioactive decay of ${ }^{87} \mathrm{Rb}$ (rubidium), strontium isotope ratios in a geological region are a function of the geochemical composition and the age of rocks (Bentley, 2006). The abundances of ${ }^{87} \mathrm{Sr}$ are normalized to the non-radiogenic ${ }^{86} \mathrm{Sr}$ and are reported as the ${ }^{87} \mathrm{Sr} /{ }^{86} \mathrm{Sr}$ ratio in order to allow for comparison among different samples (Bentley, 2006); the ${ }^{87} \mathrm{Sr} /{ }^{86} \mathrm{Sr}$ ratio in different geological terrains ranges roughly between 0.700 and 0.750 (Price et al., 2002).

Strontium moves from bedrock into the food chain via soil and groundwater. It ultimately is incorporated into the human skeleton by substituting for calcium in the crystalline lattice of hydroxyapatite of skeletal tissues due to the similar chemical structure of the two elements
(Bentley, 2006; Ezzo, 1994; Price et al., 2002). Contrary to strontium elemental concentrations which vary according to trophic level, radiogenic strontium isotope ratios are not substantially fractionated by biological processes. The radiogenic strontium isotopic composition of human bone and teeth therefore reflect the isotopic composition of the individual's diet and water sources, which in turn reflect the bioavailable strontium of the geological region and habitat from which the food and water sources were obtained (Price et al., 2002). Specifically, dental enamel reflects the composition of the strontium sources consumed during infancy and childhood because it forms during this period and does not remodel. In consequence, differences between the isotopic signature of tooth enamel and the isotopic signature of the region in which the individual died can reveal changes in the residence history of the individual, as long as local food and water sources were consumed (Price et al., 2002). However, due to the vast variability of geological formations, different locations can have similar geochemical signatures; therefore, possible mobility between geochemically similar regions will not be expressed in the skeletal elements (Burton et al., 2003).

\section{Stable oxygen isotope analysis}

Oxygen occurs in three stable isotopes, ${ }^{16} \mathrm{O}(99.765 \%)$, ${ }^{18} \mathrm{O}(0.1995 \%)$ and ${ }^{17} \mathrm{O}(0.0355 \%)$, and it is the most abundant chemical element in the earth's oceans and the second most abundant in the atmosphere (Kendall and Caldwell, 1998). Oxygen isotope data $\left(\delta^{18} \mathrm{O}_{c(\mathrm{~V}-\mathrm{PDB})}\right)$ are reported relative to the V-PDB (Vienna PeeDee belemnite) carbonate standard and are expressed in per mil (\%o) using the following standard formula: $\delta^{18} \mathrm{O}=\left(\left(\left({ }^{18} \mathrm{O} /{ }^{16} \mathrm{O}_{\text {sample }}\right) /\left({ }^{18} \mathrm{O} /{ }^{16} \mathrm{O}_{\text {standard }}\right)\right)-\right.$ 1) $\times 1,000$ (Coplen, 1994; Craig, 1961) .

Oxygen is incorporated into the minerals of the human skeleton mainly via the ingestion of water $\left(\delta^{18} \mathrm{O}_{w}\right)$ (Luz and Kolodny, 1985). Due to the isotopic equilibrium between ingested water and bioapatite when the body temperature is constant, hydroxyapatite carbonate and phosphate will reflect meteoric water values (Balasse and Ambrose, 2002; Longinelli, 1984). Oxygen isotope signatures in water sources vary according to a number of environmental factors, including altitude, latitude, distance from the coast, precipitation, temperature and humidity (e.g., Craig, 1961; Kohn, 1996; Kohn et al., 1996; Luz and Kolodny, 1985; Sponheimer and Lee-Thorp, 1999). Thus, given that local water sources were used, oxygen isotope values from hydroxyapatite will reflect the isotopic composition of the local environment during tooth and bone formation. Several studies have shown that the correlation of the $\delta^{18} \mathrm{O}_{c}$ with meteoric water makes it useful for assessing residence and mobility across different environmental zones (Land et al., 1980; Kohn and Law, 2006). However, a number of factors, including utilization of a variety of drinking water sources, storage and preparation of drinking water, as well as enrichment in ${ }^{18} \mathrm{O}$ due to breastfeeding, can affect human $\delta^{18} \mathrm{O}$ values (Knudson, 2009). 


\section{Stable carbon isotope analysis}

Carbon occurs in two stable isotopes, ${ }^{12} \mathrm{C}$ representing 99\% of the element, and ${ }^{13} \mathrm{C}$ representing the remainder $1 \%$ (Smith, 1972). Carbon isotope ratios $\left(\delta^{13} \mathrm{C}_{\mathrm{c}(\mathrm{V}-\mathrm{PDB})}\right)$ are reported relative to the V-PDB (Vienna PeeDee belemnite) carbonate standard and are expressed in per mil (\%o) using the following standard formula: $\delta^{13} \mathrm{C}=\left(\left(\left({ }^{13} \mathrm{C} /{ }^{12} \mathrm{C}_{\text {sample }}\right) /\right.\right.$ $\left.\left.\left({ }^{13} \mathrm{C} /{ }^{12} \mathrm{C}_{\text {standard }}\right)\right)-1\right) \times 1000$ (Coplen, 1994).

During the process of photosynthesis, plant tissues incorporate ${ }^{12} \mathrm{C}$ preferentially relative to ${ }^{13} \mathrm{C}$, such that the atmospheric ${ }^{13} \mathrm{C} /{ }^{12} \mathrm{C}$ ratio is greater than the one in plant tissues; a process termed fractionation. Plants are categorized relative to the different photosynthetic pathways that they use to fix atmospheric $\mathrm{CO}_{2}$ : briefly, plants as maize, millet, and other tropical grasses use the $\mathrm{C}_{4}$ (or Hatch-Slack) pathway, whereas most plants, including grass, woody shrubs and trees, use the $\mathrm{C}_{3}$ (or Calvin) pathway (Smith and Epstein, 1971). In general, $\mathrm{C}_{4}$ plants demonstrate less negative $\delta^{13} \mathrm{C}$ values with an average of $-12.5 \%$, contrary to $\mathrm{C}_{3}$ plants that exhibit more negative $\delta^{13} \mathrm{C}$ values with an average of $-26.5 \%$ (Smith, 1972; Smith and Epstein, 1971; Vogel, 1978). Furthermore, the carbon isotopic composition of the diet is represented in the consumer's tissue; thus animals that consume $\mathrm{C}_{3}$ plants will have more negative $\delta^{13} \mathrm{C}$ values than ones that consume $\mathrm{C}_{4}$ plants (e.g., Ambrose et al., 1997; Ambrose and Norr, 1993; van der Merwe and Vogel, 1978). Finally, carbon isotopic values from bone collagen reflect the dietary protein, whereas carbon isotopic values from bone carbonate represent the isotopic composition of the whole diet; in humans, $\delta^{13} \mathrm{C}$ values from apatite reflect an average of the whole diet offset by $9.4 \%$ (Ambrose and Norr, 1993).

\section{MATERIALS AND LABORATORY METHODOLOGY}

Our sampling strategy was designed to provide isotopic data from tooth enamel that formed early in an individual's life. The maxillary left first incisor and the mandibular right first incisor were used for isotopic analysis from the individuals PLA-28 and PLA-159, respectively (Table 1). Radiogenic strontium and stable carbon and oxygen isotope analyses were performed on hydroxyapatite in enamel for both teeth. Tooth enamel is considered to be generally resistant to post-depositional chemical alteration (Budd et al., 2000; Lee-Thorp and
Sponheimer, 2003; Sillen, 1989). However, it should be noted that since contamination results from the local post-depositional environment, it may cause a false local signal, but not the reverse, making non-local signatures significant (Price et al., 2006). In order to characterize the local strontium isotopic signature, burial soil from Plaza del Castillo was also sampled and analyzed.

The enamel and soil samples were prepared at the Archaeological Chemistry Laboratory at Arizona State University. Teeth were first cast and photographed, and they were mechanically cleaned by abrasion in order to remove any adhering organic matter or contaminants, as well as the outermost layers of tooth which are most susceptible to diagenetic contamination (Budd et al., 2000; Montgomery et al., 1999; Waldron, 1981, 1983; Waldron et al., 1979). Approximately 10 milligrams of tooth enamel were then removed with a Dremel Minimite-750 cordless drill equipped with an engraving cutter. The type and the color of the soil sample were first characterized according to Munsell soil color charts. Approximately two grams were first dried at $120^{\circ} \mathrm{C}$ for 48 hours, and then ashed at $800^{\circ} \mathrm{C}$ for 10 hours.

Radiogenic strontium isotope analysis was performed at the W.M. Keck Foundation Laboratory for Environmental Biogeochemistry at Arizona State University. Eight milligrams of tooth enamel powder were dissolved in $0.50 \mathrm{~mL}$ of $5 \mathrm{M} \mathrm{HNO}_{3}$. The dissolved tooth enamel was evaporated and further dissolved in $0.25 \mathrm{~mL}$ of $5 \mathrm{M} \mathrm{HNO}_{3}$. One hundred milligrams of soil were dissolved in $5.0 \mathrm{~mL}$ of $5 \mathrm{M} \mathrm{HNO}_{3}$ and in $1.0 \mathrm{~mL}$ of HF. The soil sample was evaporated and further dissolved in $1.0 \mathrm{~mL}$ of $5 \mathrm{M} \mathrm{HNO}_{3^{\prime}}$ $3.0 \mathrm{~mL}$ of $\mathrm{HCl}$ and $0.5 \mathrm{~mL}$ of $\mathrm{HF}$. Following this procedure the sample was again evaporated and further dissolved in $1.0 \mathrm{~mL}$ of $5 \mathrm{M} \mathrm{HNO}_{3}$. Strontium was separated from the sample matrix using EiChrom SrSpec resin, a crown-ether Sr-selective substance (100-150 $\mu \mathrm{m}$ diameter), and then loaded into the tip of a glass column. Total resin volume was approximately $50 \mu \mathrm{L}$. Resin was used once for sample elution and discarded. The SrSpec resin was pre-soaked and flushed with $\mathrm{H}_{2} \mathrm{O}$ to remove strontium present from the resin manufacturing process. The resin was further cleaned in the column with repeated washes of deionized $\mathrm{H}_{2} \mathrm{O}$ and conditioned with $750 \mu \mathrm{L}$ of $\mathrm{HNO}_{3}$. The dissolved sample was loaded in $250 \mu \mathrm{L}$ of $5 \mathrm{M} \mathrm{HNO}_{3}$, washed in 500 $\mu \mathrm{L}$ of $5 \mathrm{M} \mathrm{HNO3}$, and then the strontium was eluted with $1000 \mu \mathrm{L}$ of $\mathrm{H}_{2} \mathrm{O}$.

TABLE 1. Heavy and light isotope data for archaeological human enamel and soil from Plaza del Castillo, Pamplona

\begin{tabular}{ccccccc}
\hline $\begin{array}{c}\text { Laboratory } \\
\text { Number }\end{array}$ & $\begin{array}{c}\text { Specimen } \\
\text { Number }\end{array}$ & Material $^{a}$ & $\begin{array}{c}\text { Corrected } \\
{ }^{87} \mathrm{Sr} /{ }^{86} \mathrm{Sr}\end{array}$ & $\begin{array}{c}\delta^{13} \mathrm{C}_{\mathrm{c}(\mathrm{V}-\mathrm{PDB})} \\
(\% \mathrm{o})\end{array}$ & $\begin{array}{c}\delta^{18} \mathrm{O}_{\mathrm{c}(\mathrm{V}-\mathrm{PDB})} \\
(\% \mathrm{o})\end{array}$ & $\begin{array}{c}\delta^{18} \mathrm{O}_{\text {dw(V-SMOW })} \\
(\% \mathrm{o})\end{array}$ \\
\hline ACL-0400 & PLA-28 & ULI1 & 0.70797 & -16.33 & -9.65 & -16.1 \\
ACL-0401 & PLA-159 & LRI1 & 0.70817 & -13.57 & -5.64 & -9.8 \\
ACL-0439 & PLA-0001 & Soil & 0.71119 & NA & NA & NA \\
\hline
\end{tabular}

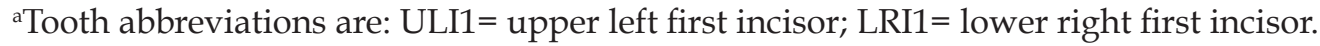


The enamel and soil samples were analyzed in a Neptune multi-collector inductively coupled plasma mass spectrometer (MC-ICP-MS) at the W.M. Keck Foundation Laboratory. On April 14, 2007, when the human enamel samples were analyzed, ${ }^{87} \mathrm{Sr} /{ }^{86} \mathrm{Sr}$ analyses of strontium carbonate standard SRM-987 yielded a value of ${ }^{87} \mathrm{Sr} /{ }^{86} \mathrm{Sr}=$ $0.71031 \pm 0.00003(2 \sigma, \mathrm{n}=18)$. On December 7, 2007, when the soil sample was analyzed, ${ }^{87} \mathrm{Sr} /{ }^{86} \mathrm{Sr}$ analyses of strontium carbonate standard SRM-987 yielded a value of ${ }^{87} \mathrm{Sr} /{ }^{86} \mathrm{Sr}=0.71028 \pm 0.00003(2 \sigma, \mathrm{n}=14)$. These data can be compared to analyses of SRM-987 using a thermal ionization mass spectrometer (TIMS), where ${ }^{87} \mathrm{Sr} /{ }^{86} \mathrm{Sr}=$ $0.710263 \pm 0.000016(2 \sigma)$ (Stein et al., 1997), and analyses of SRM-987 using an identical MC-ICP-MS, where ${ }^{87} \mathrm{Sr} /{ }^{86} \mathrm{Sr}=$ $0.710251 \pm 0.000006(2 \sigma)$ (Balcaen et al., 2005).

For oxygen and carbon isotope analysis, approximately 5 milligrams of powdered tooth enamel were treated with $0.24 \mathrm{~mL}$ of $2 \% \mathrm{NaOCl}$ and then $0.24 \mathrm{~mL}$ of $0.1 \mathrm{M} \mathrm{CH}_{3} \mathrm{COOH}$. Carbonate isotopic analyses were performed on a Finnigan MAT 253 stable isotope ratio mass spectrometer (IRMS) at the W.M. Keck Foundation Laboratory. Replicates of NBS19 resulted in a reproducibility of $\pm 0.2 \%$ for $\delta^{18} \mathrm{O}$ and $\pm 0.2 \%$ or for $\delta^{13} \mathrm{C}$. When necessary, the following conversion equations were used: $\delta^{18} \mathrm{O}_{\text {VSMOW }}=\left(1.03091 \times\left(\delta^{18} \mathrm{O}_{\text {VPDB }}\right)\right)+$ $30.91, \delta^{18} \mathrm{O}_{\text {VPDB }}=\left(0.97002 \times \delta^{18} \mathrm{O}_{\text {VSMOW }}\right)-29.98, \delta^{18} \mathrm{O}_{\text {c(VSMOW })}$ $=\left(8.5+\left(\delta^{18} \mathrm{O}_{\mathrm{p}}\right)\right) / 0.98$, and $\delta^{18} \mathrm{O}_{\mathrm{p}(\mathrm{VSMOW})}=\left(0.64 \times\left(\delta^{18} \mathrm{O}_{\mathrm{dw}}\right)\right)+$ 22.37 (Coplen et al., 1983; Iacumin et al., 1996; Müller et al., 2003; Wolfe et al., 2001).

\section{RESULTS}

The enamel sample from individual PLA-28 exhibits ${ }^{87} \mathrm{Sr} /{ }^{86} \mathrm{Sr}=0.70797, \delta^{18} \mathrm{Oc}=-9.7 \%$, and $\delta^{13} \mathrm{C}_{\mathrm{c}}=-16.3 \%$ o (Table $1)$. The enamel sample from individual PLA-159 exhibits ${ }^{87} \mathrm{Sr} /{ }^{86} \mathrm{Sr}=0.70817, \delta^{18} \mathrm{O}_{\mathrm{c}}=-5.6$, and $\delta^{13} \mathrm{C}_{\mathrm{c}}=-13.6 \%$ o (Table 1). Using the previously-discussed conversion equations the $\delta^{18} \mathrm{O}$ values from the enamel were converted to likely drinking water values $\delta^{18} \mathrm{O}_{\text {dw(V-SMOW })}=-16.1 \%$ for PLA-28, and $\delta^{18} \mathrm{O}_{\mathrm{dw}(\mathrm{V}-\mathrm{SMOW})}=-9.8 \%$ o for PLA-159 (Table 1). The soil sample shows a ratio of ${ }^{87} \mathrm{Sr} /{ }^{86} \mathrm{Sr}=0.71119$ (Table 1$)$.

\section{DISCUSSION}

Before we turn to the interpretation of the biogeochemical results, we will briefly examine the geochemical setting of the study area. Pamplona basin is located in the western part of the Southern Pyrenean Foreland Basin, and consists of geologic transitional marine and terrestrial deposits that formed in the Lower to Middle Eocene (Payros et al., 1999). The Valle de Tena in Huesca province, located to the northeast of Pamplona, is characterized by Silurian to Permian and Cretaceous carbonate and detrital sedimentary rocks, with the Paleozoic limestones showing isotopic values of ${ }^{87} \mathrm{Sr} /{ }^{86} \mathrm{Sr}=0.70510-0.70970$ (Subías et al., 1998) (Fig. 1). The deposits of fluorites and calcites in the area exhibit isotopic ranges of ${ }^{87} \mathrm{Sr} /{ }^{86} \mathrm{Sr}=0.70850-0.71083$ in Portalet, ${ }^{87} \mathrm{Sr} /{ }^{86} \mathrm{Sr}=$ $0.70858-0.71036$ in Lanuza, and ${ }^{87} \mathrm{Sr} /{ }^{86} \mathrm{Sr}=0.70911-0.71010$ in Tebarray (Subías et al., 1998). Furthermore, the andes- ites in Anayet exhibit a ratio of ${ }^{87} \mathrm{Sr} /{ }^{86} \mathrm{Sr}=0.70582-0.70752$ (Innocent et al., 1994) (Fig. 1). The volcanic and intrusive alkaline rocks in Oloron in southern France show an isotopic range of ${ }^{87} \mathrm{Sr} /{ }^{86} \mathrm{Sr}=0.70535-0.70623$ (Rossy et al., 1992) (Fig. 1). To the west of Pamplona, basalts from the region of Bilbao in the Spanish Basque Country give an isotopic range of ${ }^{87} \mathrm{Sr} /{ }^{86} \mathrm{Sr}=0.70376-0.70542$ (Rossy et al., 1992) (Fig. 1).

In order to control for the wide petrographic diversity and intraregional bedrock variation, soil from Plaza del Castillo was used to determine the local isotopic baseline of the area for this preliminary study. When radiogenic strontium isotopic signatures from both enamel samples are compared to the local geochemical signal for the soil, they prove to be considerably lower (Table 1). This may indicate that both individuals were born and spent at least early childhood in a different location and moved to Pamplona later in life, assuming local dietary and water sources were consumed.

In an attempt to trace the geographic origins of both individuals and thus test the hypothesis of a North African provenance, isotopic signatures from enamel were compared to radiogenic strontium isotopic ratios reported for Africa. In northeastern Morocco, the region approximately $100 \mathrm{~km}$ southwest to the city of Oujda shows a series of granodiorites with ratios of ${ }^{87} \mathrm{Sr} /{ }^{86} \mathrm{Sr}=0.70693$ 0.70972 (Ajaji et al., 1998). Groundwater sampled across numerous locations along the Continental Intercalaire aquifer system, spanning from the Saharan Atlas of Algeria to the Chotts region of southern Tunisia, yields isotopic ratios of ${ }^{87} \mathrm{Sr} /{ }^{86} \mathrm{Sr}=0.707826-0.70939$ (Edmunds et al., 2003). Furthermore, cumulate rock sequences at Laouni, Hoggar, in southern Algeria exhibit a range of ${ }^{87} \mathrm{Sr} /{ }^{86} \mathrm{Sr}=$ 0.70305-0.70669 (Cottin et al., 1998). Finally, soil samples and modern faunal samples collected in the Gobero area in central Niger show average ratios of ${ }^{87} \mathrm{Sr} /{ }^{86} \mathrm{Sr}=0.71290$ $\pm 0.00064(1 \sigma)$ and ${ }^{87} \mathrm{Sr} /{ }^{86} \mathrm{Sr}=0.71261 \pm 0.00116(1 \sigma)$, respectively (Sereno et al., 2008). Hence, the radiogenic strontium isotopic signatures of the two individuals analyzed from Plaza del Castillo generally match the radiogenic strontium isotopic ratios from northeastern Morocco, thus supporting a North African origin of Berber groups, such as those who colonized Medieval Pamplona during the early Medieval period.

The enamel radiogenic strontium isotope signatures from Plaza del Castillo are also consistent with some marine strontium sources, averaged with strontium from a geologic zone or zones with lower strontium isotope signatures. Since seawater is characterized by ${ }^{87} \mathrm{Sr} /{ }^{86} \mathrm{Sr}=$ 0.7092 (Veizer, 1989), these individuals may have obtained some, though not all, of their strontium in the first years of life from marine sources. However, according to the results from stable carbon isotope analysis discussed below this interpretation is unlikely, given that marine food consumption was not a major component of the diet of the two individuals. 
Given that the climate in northern Spain is considered to be relatively stable since the eighth century A.D., modern $\delta^{18} \mathrm{O}_{\mathrm{V}-\text { SMOW }}$ values from precipitation were used to determine the local range of $\delta^{18} \mathrm{O}_{\mathrm{v} \text {-SMow }}$. Due to the lack of available precipitation values for Pamplona, precipitation $\delta^{18} \mathrm{O}_{\mathrm{V} \text { SMOW }}$ values measured in Saragossa (Fig. 1) were used to determine the probable $\delta^{18} \mathrm{O}_{\mathrm{V}-\mathrm{sMOW}}$ values in Pamplona (IAEA/WMO, 2006). Oxygen isotope signatures in precipitation collected in the Saragossa station in 2000-2001, showed a range from $\delta^{18} \mathrm{O}_{\text {v-SMOW }}=-10.8 \%$ to $\delta^{18} \mathrm{O}_{\mathrm{V} \text {-SMOW }}=$ $1.67 \%$, with an average value of $\delta^{18} \mathrm{O}_{\mathrm{v}-\mathrm{SMOW}}=-5.9(\mathrm{n}=24)$ (IAEA/WMO, 2006), which was used as the probable local range of $\delta^{18} \mathrm{O}_{\mathrm{V} \text {-SMow }}$ for Pamplona. When the drinking water values from Plaza del Castillo are compared to the modern precipitation values from Saragossa, the $\delta^{18} \mathrm{O}_{\mathrm{v} \text {-smow }}$ value for individual PLA-28 (-16.1\%o) falls outside the range of the observed precipitation values. The $\delta^{18} \mathrm{O}_{\mathrm{V} \text {-smow }}$ value for PLA-159 (-9.8\%o) appears within the local precipitation range; however, it is very close to the lower limit. Thus, analysis of $\delta^{18} \mathrm{O}_{\mathrm{V}-\mathrm{SMOW}}$ values may indicate that these two individuals lived outside of the Pamplona region during enamel formation, paralleling results from the strontium analysis.

As mentioned, bone carbonate reflects the isotopic composition of the diet plus $9.4 \%$ o (Ambrose and Norr, 1993). Therefore, subtracting $9.4 \%$ o from the measured archaeological human enamel $\delta^{13} \mathrm{C}_{\mathrm{c}(\mathrm{V}-\mathrm{PDB})}$ values shows that they correspond to a diet based heavily on $\mathrm{C}_{3}$ plants and/or animals that consumed $\mathrm{C}_{3}$ plants (Table 1 ). The reconstruction of a diet based on terrestrial $C_{3}$ plants, like cereals, is consistent with either African or Spanish early childhood residence.

\section{CONCLUSIONS}

Overall, the presence of two first-generation immigrants at the Islamic cemetery of Plaza del Castillo was successfully identified through isotopic analyses. The two individuals (PLA-28, PLA-159) showed non-local isotopic signatures suggesting movement to Pamplona from a different geographic location sometime after early childhood. An origin from northern Africa, as suggested by the typological analysis of the dental modifications in PLA-159, is consistent with the isotopic results. Dental decoration, the apparent early date for at least part of the cemetery and these isotopic results suggest that the individuals included in the study may have come to Pamplona from North Africa, perhaps as part of the military expedition to control the local revolutions of the time against the recently established Muslim authority. The fact that individual PLA-159 is a female further indicates that the incoming Muslim population was not formed exclusively by men with a military function, but rather by family groups and/or camp followers.

Given the promising results of this preliminary study, future research consisting of isotopic analysis of a larger sample size, representative of the maqbara, will allow for a complete examination of the residential histories of the individuals buried in Plaza del Castillo and will inform our understanding of the migration of African groups in eighth century A.D. Pamplona during the initial Islamization of the city. In addition, a vital direction for further research is the continued characterization of baseline isotopic and elemental data from Pamplona and the surrounding region, including the bioavailable strontium isotope ratios in the study region and paleoenvironmental reconstructions. Detailed data on strontium isotope ratios in exposed bedrock samples from the geological literature should be supplemented with strontium isotope analysis of modern and archaeological small mammals from the study region. This will facilitate characterization of local strontium isotope signatures and a more informed interpretation of the geographic origin of the individuals interred in Plaza del Castillo. In conclusion, the present study exemplifies the use of biogeochemistry as an analytical tool, and provides a new perspective to the Muslim diaspora in northern Spain.

\section{ACKNOWLEDGMENTS}

We would like to thank A. Anbar and E. Shock for access to the W.M. Keck Foundation Laboratory for Environmental Biogeochemistry at ASU and postdoctoral associates Gwyneth Gordon and Anthony Michaud for assistance with sample analysis. We would like to thank also M. Unzu and the archaeological company Trama S.L. in Pamplona. The study was funded by the Archaeological Chemistry Laboratory and the Center for Bioarchaeological Research at ASU. Eleanna Prevedorou received a scholarship by the Public Benefit Foundation Alexander S. Onassis during the time of this study.

\section{LITERATURE CITED}

Ajaji T, Weis D, Giret A, Bouabdellah M. 1998. Coeval potassic and sodic calc-alkaline series in the postcollisional Hercynian Tanncherfi intrusive complex, northeastern Morocco: geochemical, isotopic and geochronological evidence. Lithos 45:371-393.

Al-Marrakusi II. 1999. Historia de Al-Andalus. Trans. F. Fernández González (1860) Málaga: Aljaima.

Ambrose SH, Butler BM, Hanson DB, Hunter-Anderson RL, Krueger HW. 1997. Stable isotopic analysis of human diet in the Marianas Archipelago, western Pasific. Am J Phys Anthropol 104:343-361.

Ambrose SH, Norr L. 1993. Experimental evidence for the relationship of carbon isotope ratios of whole diet and dietary protein to those of bone collagen and carbonate. In: Lambert JB, and Grupe G, editors. Prehistoric human bone: Archaeology at the molecular level. Berlin: Springer-Verlag. p 1-38.

Balasse M, Ambrose SH. 2002. The seasonal mobility model for prehistoric herders in the south-western Cape of South Africa assessed by isotopic analysis of sheep tooth enamel. J Archaeol Sci 29:917-932. 
Balcaen L, Schrijver ID, Moens L, Vanhaecke F. 2005. Determination of the $87 \mathrm{Sr} / 86 \mathrm{Sr}$ isotope ratio in USGS silicate reference materials by Multi-Collector ICPMass Spectrometry. Int J Mass Spectrom 24:251-255.

Bentley RA. 2006. Strontium isotopes from the earth to the archaeological skeleton: a review. J Archaeol Method Th 13:135-187.

Bentley RA, Knipper C. 2005. Geographical patterns in biologically available strontium, carbon and oxygen isotope signatures in prehistoric SW Germany. Archaeometry 47(3):629-644.

Bentley RA, Price DT, Stephan E. 2004. Determining the "local" 87Sr/86Sr range for archaeological skeletons: A case study from Neolithic Europe. J Archaeol Sci 31:365-375.

Bentley RA, Tayles N, Higham C, Macpherson C, Atkinson TC. 2007. Shifting gender relations at Khok Phanom Di, Thailand: Isotopic evidence from the skeletons. Curr Anthropol 48:301-314.

Budd P, Montgomery J, Barreiro B, Thomas RG. 2000. Differential diagenesis of strontium in archaeological human dental tissues. Appl Geochem 15:687-694.

Burton JH, Price DT, Wright LE. 2003. The use of barium and strontium abundances in human skeletal tissues to determine their geographic origins. Int J Osteoarchaeol 13:88-95.

Campillo D, Pérez-Pérez A, Rovira J. 2001. Analyse microscopique de mutilations dentaires posthumes dans la Préhistoire de la Péninsule Ibérique. In: Hadjouis D, and B. M, editors. La Paléo-Odontologie Analyses et Méthodes d'étudeCollection Paléoanthropologie et Paléopathologie osseuse: Éditions Artcom. p 171-180.

Casal MT. 2003. Los cementerios musulmanes de Qurtuba. Universidad de Córdoba.

Coplen TB. 1994. Reporting of stable hydrogen, carbon, and oxygen isotopic abundances. Pure Appl Chem 66:273-276.

Coplen TB, Kendall C, Hopple J. 1983. Comparison of stable isotope reference samples. Nature 302:236-238.

Cottin JY, Lorand JP, Agrinier P, Bodinier JL, Liégeois JP. 1998. Isotopic $(\mathrm{O}, \mathrm{Sr}, \mathrm{Nd})$ and trace element geochemistry of the Laouni layered intrusions (Pan-African belt, Hoggar, Algeria): evidence for postcollisional continental tholeiitic magmas variably contaminated by continental crust. Lithos 45:197-222.

Cox G, Sealy J. 1997. Investigating identity and life histories: Isotopic analysis and historical documentation of slave skeletons found on the Cape Town foreshore, South Africa. Int J Hist Archaeol 1:207-224.

Craig H. 1961. Isotopic variations in meteoric waters. Science 133:1702-1703.

De Miguel Ibáñez MP. 2007. La maqbara de la Plaza del Castillo (Pamplona, Navarra): avance del estudio osteoarqueológico. In: Senác $\mathrm{P}$, editor. Villes et campagnes de la Tarraconaise et d'Al-Andalus (VIe-XIe siècle): la transition: CNS-Université de Toulouse-Le Mirail. p 183-197.
Díaz-Zorita Bonilla M, Waterman AJ, Knudson KJ. 2009. Explorando la movilidad y los patrones dietarios durante la Edad del Cobre en el Suroeste de la Península Ibérica: estudio preliminar bioarqueológico del Tholos de Palacio III (Almadén de la Plata, Sevilla). Actas del IX Congreso Nacional de Paleopatología Morella (Castellón) 26-29 de Septiembre de 2007. p 669-674.

Edmunds WM, Guendouz AH, Mamou A, Moulla A, Shand P, Zouari K. 2003. Groundwater evolution in the Continental Intercalaire aquifer of southern Algeria and Tunisia: trace element and isotopic indicators. Appl Geochem 18:805-822.

Ezzo JA. 1994. Putting the "chemistry" back into archeological bone chemistry analysis: modeling potential paleodietary indicators. J Anthropol Archaeol 13:1-34.

Ezzo JA, Johnson CM, Price DT. 1997. Analytical perspectives on prehistoric migration: a case study from east-central Arizona. J Archaeol Sci 24:447-466.

Ezzo JA, Price DT. 2002. Migration, regional reorganization, and spatial group composition at Grasshopper Pueblo, Arizona. J Archaeol Sci 29:499-520.

Faro Carballa JA, García-Barberena Unzu M, Unzu Urmeneta M. 2007. La presencia islámica en Pamplona. In: Senác $\mathrm{P}$, editor. Villes et campagnes de la Tarraconaise et d'Al-Andalus (VIe-XIe siècle): la transition: CNSUniversité de Toulouse-Le Mirail. p 97-138.

Faro Carballa JA, García-Barberena Unzu M, Unzu Urmeneta M. 2007-2008. Pamplona y el Islam. Nuevos testimonios arqueológicos. Trabajos de Arqueología Navarra 20:229-284.

Fastlicht S. 1976. Tooth mutilation and dentistry in PreColumbian Mexico. Berlin: Quintessenz.

Finucane BC, Manning K, Touré M. 2008. Prehistoric dental modification in Western Africa-Early evidence from Karkarichinkat nord, Mali. Int J Osteoarchaeol 18:632-640.

Galbany J, Estebaranz F, Martínez LM, Romero A, De Juan J, Turbón D, Pérez-Pérez A. 2006. Comparative analysis of dental enamel polyvinylsiloxane impression and polyurethane casting methods for SEM research. Microsc Res Tech 69:246-252.

Gonzalo J, Trancho GJ, Robledo B. 2001. Modificaciones intencionales de la corona dental: la mutilación dentaria. In: Campo Martín M, and Robles Rodríguez F, editors. ¿Dónde estamos? Pasado, presente y futuro de la Paleopatología. Madrid: UAM and AEP. p 359366.

Goose DH. 1963. Tooth-mutilation in West Africans. Man 63:91-93.

Gould AR, Farman AG, Corbitt D. 1984. Mutilations of the dentition in Africa: a review with personal observations. Quintessence Int Dent Dig 1:89-94.

Haour A, Pearson JA. 2005. An instance of dental modification on a human skeleton from Niger, West Africa. Oxford J Archaeol 24:427-433. 
Iacumin P, Bocherens H, Mariotti A, Longinelli A. 1996. Oxygen isotope analysis of co-existing carbonate and phosphate in biogenic apatite: a way to monitor diagenetic alteration of bone phosphate? Earth Planet Sci Lett 142:1-6.

IAEA/WMO. 2006. Global Network of Isotopes in Precipitation. The GNIP Database. Accessible at http:/ / isohis.iaea.org.

Innocent C, Briqueu L, Cabanis B. 1994. Sr-Nd isotope and trace element geochemistry of late Variscan volcanism in the Pyrenees: magmatism in post-orogenic extension? Tectonophysics 238:161-181.

Jones A. 1992. Tooth mutilations in Angola. British Dent J 173:177-179.

Kendall C, Caldwell EA. 1998. Fundamentals of isotope geochemistry. In: Kendall C, and McDonell JJ, editors. Isotope tracers in catchment hydrology: Elsevier. $\mathrm{p}$ 51-86.

Knudson KJ. 2009. Oxygen isotope analysis in a land of environmental extremes: The complexities of isotopic work in the Andes. Int J Osteoarchaeol 19:171-191.

Knudson KJ, Buikstra JE. 2007. Residential mobility and resource use in the Chiribaya polity of Southern Peru: Strontium isotope analysis of archaeological tooth enamel and bone. Int J Osteoarchaeol 17:563-580.

Knudson KJ, Price DT. 2007. Utility of multiple chemical techniques in archaeological residential mobility studies: Case studies from Tiwanaku- and Chiribayaaffiliated sites in the Andes. Am J Phys Anthropol 132:25-39.

Knudson KJ, Torres-Rouff C. 2009. Investigating cultural heterogeneity in San Pedro de Atacama, Northern Chile, through biogeochemistry and bioarchaeology. Am J Phys Anthropol 138:473-485.

Kohn MJ. 1996. Predicting animal $\delta^{18} \mathrm{O}$ : Accounting for diet and physiological adaptation. Geochim Cosmochim Acta 60:4811-4829.

Kohn MJ, Law M. 2006. Stable isotope chemistry of fossil bone as a new paleoclimate indicator. Geochim Cosmochim Acta 70:931-946.

Kohn MJ, Schoeninger MJ, Valley JW. 1996. Herbivore tooth oxygen isotope compositions: Effects of diet and physiology. Geochim Cosmochim Acta 60:3889-3896.

Lagunas Z, Karam CE. 2003. Cráneos africanos de la época colonial con mutilación dentaria, procedentes del ex Hospital Real de San José de los Naturales de la ciudad de México, D. F. Estudios de Antropología Biológica 11:967-981.

Land LS, Lundellius EL, Valastro S. 1980. Isotopic ecology of deer bones. Paleogeogr Paleoclimatol Paleoecol 32:143-151.

Lee-Thorp J, Sponheimer M. 2003. Three case studies used to reassess the reliability of fossil bone and enamel isotope signals for paleodietary studies. J Anthropol Archaeol 22:208-216.

Longinelli A. 1984. Oxygen isotopes in mammal bone phosphate: A new tool for paleohydrological and paleoclimatological research? Paleogeogr Paleoclimatol Paleoecol 32:143-151.

Luz B, Kolodny Y. 1985. Oxygen isotope variations in phosphate of biogenic apatites, IV. Mammal teeth and bones. Earth Planet Sci Lett 75:29-36.

Montgomery J, Budd P, Cox A, Krause P, Thomas RG. 1999. LA-ICP-MS evidence for the distribution of lead and strontium in Romano-British, Medieval and modern human teeth: Implications for life history and exposure reconstruction. In: Young SMM, Pollard AM, Budd P, and Ixer RA, editors. Metals in Antiquity BAR International Series No 792. Oxford: British Archaeological Reports. p 290-296.

Montgomery J, Evans JA, Powlesland D, Roberts CA. 2005. Continuity or colonization in Anglo-Saxon England? Isotope evidence for mobility, subsistence practice, and status at West Heslerton. Am J Phys Anthropol 126:123138.

Müller W, Fricke H, Halliday AN, McCulloch MT, Wartho J-A. 2003. Origin and migration of the Alpine Iceman. Science 302:862-866.

Muwazi LM, Charles M, Rwenyonyi CM, Francis J, Tirwomwe FJ, Ssali C, Kasangaki A, Nkamba ME, Ekwaru P. 2005. Prevalence of oral diseases/conditions in Uganda. Afr Health Sci 5:227-233.

Nafplioti A. 2008. 'Mycenean' political domination of Knossos following the Late Minoan IB destructions on Crete: negative evidence from strontium isotope analysis (87Sr/86Sr). J Archaeol Sci 35:2307-2317.

Payros A, Pujalte V, Orue-Etxebarria X. 1999. The South Pyrenean Eocene carbonate megabreccias revisited: new interpretation based on evidence from the Pamplona Basin. Sediment Geol 125:165-194.

Pindborg JJ. 1969. Dental mutilation and associated abnormalities in Uganda. Am J Phys Anthropol 31:383390.

Prevedorou EA, Díaz-Zorita Bonilla M, Buikstra JE, Gordon G, Anbar A, Knudson KJ. 2009. Residential mobility and dietary patterns at the prehistoric site of Gatas, southeastern Spain. Am J Phys Anthropol 138(S48):330.

Price DT, Bentley AR, Lüning J, Gronenborn D, Wahl J. 2001. Prehistoric human migration in the Linearbandkeramik of Central Europe. Antiquity 75:593-603.

Price DT, Gestsdóttir H. 2006. The first settlers of Iceland: An isotopic approach to colonisation. Antiquity 80:130144.

Price DT, Grupe G, Schroter P. 1998. Migration and mobility in the Bell Beaker period in Central Europe. Antiquity 72:405-411.

Price DT, Tiesler V, Burton JH. 2006. Early African diaspora in colonial Mexico: Strontium isotopic evidence. Am J Phys Anthropol 130:485-490.

Price TD, Burton JH, Bentley RA. 2002. The characterization of biologically available strontium isotope ratios for the study of prehistoric migration. Archaeometry 44:117135. 
Price TD, Johnson CM, Ezzo JA, Ericson J, Burton JH. 1994. Residential mobility in the prehistoric Southwest United States: a preliminary study using strontium isotope analysis. J Archaeol Sci 21:315-330.

Reichart P, Cruetz U, Scheifele C. 2007. Dental mutilations and associated alveolar bone pathology in African skulls of the anthropological skull collection, Charité, Berlin. J Oral Pathol Med 37:50-55.

Richards M, Harvati K, Grimes V, Smith C, Smith T, Hublin J-J, Karkanas P, Panagopoulou E. 2008. Strontium isotope evidence of Neanderthal mobility at the site of Lakonis, Greece using laser-ablation PIMMS. J Archaeol Sci 35:1251-1256.

Romero A, De Juan J. 2003. Microscopic features on enamel incisor surfaces: implications as regards feeding behavior in bio-archaeological groups. Int J Dent Antrhopol 4:1-9.

Romero A, De Miguel Ibáñez MP, Buikstra JE, Knudson KJ, Prevedorou EA, Díaz-Zorita Bonilla M, De Juan J. 2009. Mutilación dentaria en la necrópolis islámica de Plaza del Castillo (Siglo VIII DC) de Pamplona (Navarra). Revista Española de Antropología Física 29:1-14.

Romero Molina J. 1958. Mutilaciones dentarias prehispánicas de México y América en general. México: Instituto Nacional de Antropología e Historia.

Romero Molina J. 1986. Catálogo de la colección de dientes mutilados prehispánicos. IV parte. Colección Fuentes. México: Instituto Nacional de Antropología e Historia.

Rossy M, Azambre B, Albarède F. 1992. REE and Sr-Nd isotope geochemistry of the alkaline magmatism from the Cretaceous North Pyrenean Rift Zone (FranceSpain). Chem Geol 97:33-46.

Rubín de la Borbolla DF. 1940. Types of tooth mutilation found in Mexico. Am J Phys Anthropol 26:349-366.

Saville MH. 1913. Precolumbian decoration of the teeth in Ecuador. With some account of the occurrence of the custom in other parts of North and South America. Am Anthropol 15:377-394.

Sereno PC, Sereno PC, Garcea EAA, Jousse H, Stojanowski CM, Saliège JF, et al. 2008. Lakeside cemeteries in the Sahara: 5000 years of Holocene population and environmental change. PLoS ONE 3 e2995. doi:2910.1371/journal.pone.0002995.

Sillen A. 1989. Diagenesis of the inorganic phase of cortical bone. In: Price DT, editor. The chemistry of prehistoric bone: Cambridge University Press. p 211-229.
Smith BN. 1972. Natural abundances of the stable isotopes of carbon in biological systems. BioScience 22:226-231.

Smith BN, Epstein S. 1971. Two categories of ${ }^{13} \mathrm{C} /{ }^{12} \mathrm{C}$ ratios for higher plants. Plant Physiology 47:380-384.

Sponheimer M, Lee-Thorp JA. 1999. Oxygen isotopes in enamel carbonate and their ecological significance. J Archaeol Sci 26:723-728.

Stein M, Starinsky A, Katz A, Goldstein SL, Machlus M, Schramm A. 1997. Strontium isotopic, chemical, and sedimentological evidence for the evolution of Lake Lisan and the Dead Sea. Geochim Cosmochim Acta 61:3975-3992.

Subías I, Moritz R, Fernández-Nieto C. 1998. Isotopic composition of strontium in the Valle de Tena (Spanish Central Pyrenees) fluorite deposits: relevance for the source of elements and genetic significance. Mineralium Deposita 33:416-424.

Tiesler V. 2002. New cases of an African tooth decoration from colonial Campeche, Mexico. Homo 52:277-282.

van der Merwe NJ, Vogel JC. 1978. ${ }^{13} \mathrm{C}$ Content of human collagen as a measure of prehistoric diet in woodland North America. Nature 276:815-816.

van Rippen B. 1918. Practices and customs of the African natives involving dental procedure. Am Anthropol 20:461-463.

Veizer J. 1989. Strontium isotopes in seawater through time. Ann Rev Earth Planet Sci 1:141-167.

Vogel JC. 1978. Isotopic assessment of the dietary habits of ungulates. S Afr J Sci 74:298-301.

Waldron HA. 1981. Postmortem absorption of lead by the skeleton. Am J Phys Anthropol 55:395-398.

Waldron HA. 1983. On the post-mortem accumulation of lead by skeletal tissues. J Archaeol Sci 10:35-40.

Waldron HA, Khera A, Walker G, Wibberly G, Green CJS. 1979. Lead concentrations in bones and soil. J Archaeol Sci 6:295-298.

White CD, Spence MW, Longstaffe FJ, Law KR. 2004. Demography and ethnic continuity in the Tlailotlacan enclave of Teotihuacan: the evidence from stable oxygen isotopes. J Anthropol Archaeol 23:385-403.

Wolfe BB, Aravena R, Abbott MB, Seltzer GO, Gibson JJ. 2001. Reconstruction of paleohydrology and paleohumidity from oxygen isotope records in the Bolivian Andes. Paleogeogr Paleoclimatol Paleoecol 176:177-192. 